\title{
The Impact of European Integration on the Nineties' Wave of Mergers and Acquisitions
}

\author{
Anne-France Delannay \\ Université Robert Schuman \\ Pierre-Guillaume Méon \\ University of Brussels
}

\begin{abstract}
The present paper applies a gravity model with fixed country effects to $M \& A$ flows on a sample of 1215 pairs of countries over the 1998-2001 period, to test the impact of European integration. That model, which had to our knowledge not been applied to $M \& A$ flows so far, allows us to observe that the participation of two countries in the process of European integration is associated with a smaller negative impact of distance on those countries' bilateral M\&A flows. We observe no such effect for the EMU however.
\end{abstract}

- JEL classification: F15, F23, G34

- Keywords: Mergers and acquisitions, multinational firms, gravity models, European integration, EMU

\section{Introduction}

International economists will remember the late nineties as a period of considerable interest. Indeed, those years first concluded a decade of repeated progress in the European process of economic integration. Namely, the nineties started with the

\footnotetext{
*Corresponding address: Pierre-Guillaume Méon, Departmente D'Economie University of Brussels DULBEA CP-140, Avenue F.D. Roosevelt, 501050 Bruxelles Belgium, Tel: (32) 265066 48, Fax: (32) 265038 25, E-mail: pgmeon@ulb.ac.be

(C2006-Center for International Economics, Sejong Institution, All Rights Reserved.
} 
completion of the Single European Act, saw the adoption of the Maastricht treaty, and culminated in the adoption of a single currency in 1999.

Second, the late nineties witnessed the peak of an unprecedented boom in international mergers and acquisitions (M\&As). To be sure, as Pryor (2001) shows, this boom was a global process, but European economies took an ample share in it. Unsurprisingly, the world boom in M\&As was accompanied with a surge in intraEuropean mergers. Thus, according to the OECD, the world-wide number of crossborder M\&As rose from 8,587 in 1990 to 24,113 in 1999. Over the same period, the number of European cross-border M\&As almost tripled. Pryor (2001) also emphasises the European participation in the global M\&As "tsunami".

Although the explosion of the M\&A activity in Europe is undoubtedly related to the global wave of M\&As, its simultaneity with the process of European integration warrants closer scrutiny. More precisely, one cannot but wonder whether the process of European integration affected the participation of European economies in the global wave of M\&As. In particular, whether European integration lead European firms to merge with, or acquire, other European, or future European, firms remains an open question.

Nevertheless, that question is of key importance both on a practical and a theoretical plane. Thus, the answer to that question is directly relevant to the debate on the home bias in international capital holdings. Namely, by determining whether the home bias extends to a European bias, a new light may be shed on the role of regional integration in fostering or limiting that bias.

Moreover, monetary integration spurred a heated debate on the capacity of the participating economies to face asymmetric shocks. A first line of contention relevant to that debate rests on the impact of monetary integration on the specialisation of member countries. Some, like Krugman (1993), have voiced their concern that increased specialisation may result in more asymmetric shocks. However, one may also argue, along the line proposed by Mélitz and Zumer (1999), that the single currency may allow larger cross-border participations in the capital of European firms, thereby improving the capacity of member countries to share macroeconomic risk. The impact of economic integration on the distribution of activities in Europe is therefore of critical practical importance, not to mention its implications for economic geography as an academic discipline.

Within that context, the study of M\&A flows deserves special attention, as their share in the total volume of foreign direct investment (FDI) has increased to an unparalleled level. Indeed, according to the OECD, the value of cross-border 
M\&As amounted to 91 percent of the value of all FDI flows in 1999. Determining whether there is a European specificity in European M\&A flows is consequently an important issue. This is precisely that issue that the present paper addresses. More precisely, it aims at determining whether M\&A flows between two countries are larger if they partake in the European integration process. However, to do so, we need a benchmark against which to weigh those countries' actual situation. Indeed, it is not sufficient to observe that European economies trade more with each other to conclude to the existence of a positive impact of economic integration. Instead, one must be able to determine that the flows of M\&As between them are larger than what they would spontaneously have been, absent the European integration process. We therefore estimate a gravity model on M\&A flows to determine the natural volume of M\&A flows between European economies.

That model basically posits that the flow of M\&As between two economies depends on the distance between them, as well as on their characteristics, including their sizes. Although it was initially designed for trade flows, it has recently been applied to capital flows, for instance by Eaton and Tamura (1994), de Ménil (1999), Portes et al. (2001), or Portes and Rey (2005). However, it has still only scarcely been specifically applied to M\&A flows. To our knowledge, the only exceptions are Ashcroft et al. (1994) and di Giovanni (2005). Furthermore, it has not been used to capture the impact of European integration, a gap that the present paper aims at filling.

Another specificity of the present study, is that it estimates the model thanks to a method that had not yet been applied to capital flows. Namely, the model is estimated by postulating fixed source and host country effects, which allows to limit the likelihood of an omitted variable bias, which is a common risk in that kind of exercise.

The present paper's motivation is therefore twofold. It first shows that a gravity model with country specific fixed effects can successfully be estimated on M\&A flows. Second, it obtains fresh estimates of the impact of European integration on M\&A flows. We thus observe that if present and future members of the European Union tend to exhibit larger M\&A flows between them than other pairs of countries, the same result is not observable among EMU members, and only for a subset of candidate countries.

To reach those conclusions, the rest of the paper is organised as follows. Section 1 sketches the quantitative and qualitative evolutions of M\&A flows in Europe in 
the nineties. Section 2 presents and motivates the method used in this paper, as well as the data on which it is applied. Section 3 displays and comments the results of our estimations. Eventually, section 4 concludes.

\section{M\&As and European Integration in the Nineties: Some Facts}

As mentioned above, cross-border mergers and acquisitions activity experienced an explosion during the nineties. As figure 1 shows, the number of deals increased especially during the last three years of the decade, as well as their value. Both the number and value of deals increased over the decade but reached a peak between 1998 and 2001.

A striking feature of that wave of M\&As is the extent to which it involved EU firms ${ }^{1}$. Figure 2 illustrates this point. It displays the geographic repartition of world outward M\&As. It shows that $45 \%$ of all cross-border M\&A operations originated from the EU in 1999. If one adds other European economies, one sees that more than one half of all deals had a European source. This impression is amply confirmed when one studies the repartition of the value of M\&A deals. It then appears that the EU alone accounted for $67 \%$ of the total value of M\&A deals in 1999.

Moreover, intra-European operations account for the bulk of the wave of crossborder M\&As. This point is made clearly by figure 3 that is devoted to the

Figure 1. Cross-border $M \&$ As

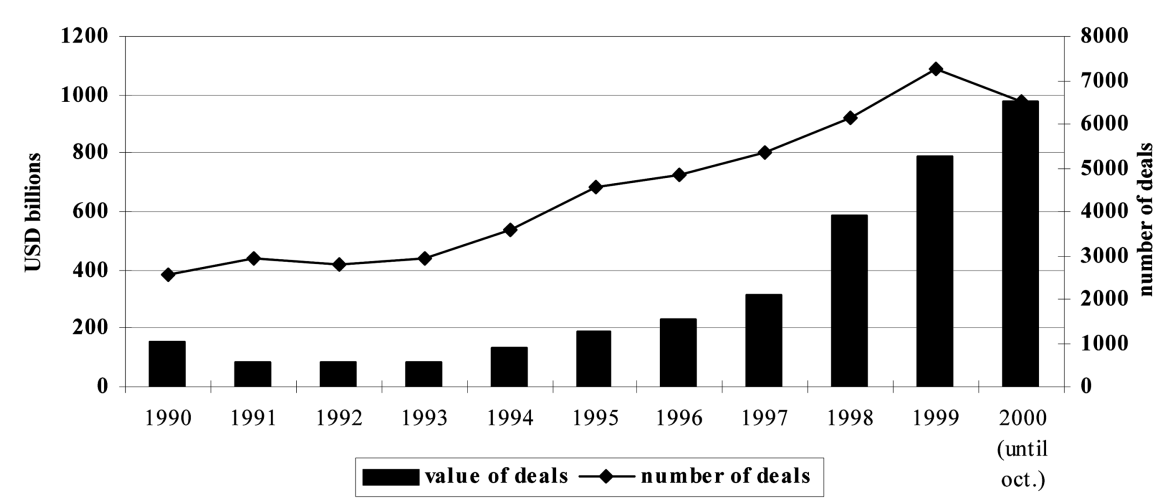

Source : OECD (2001)

\footnotetext{
${ }^{1}$ What is meant here by the EU is the then fifteen member EU.
} 
Figure 2. Number of outward M\&As by region (1999)

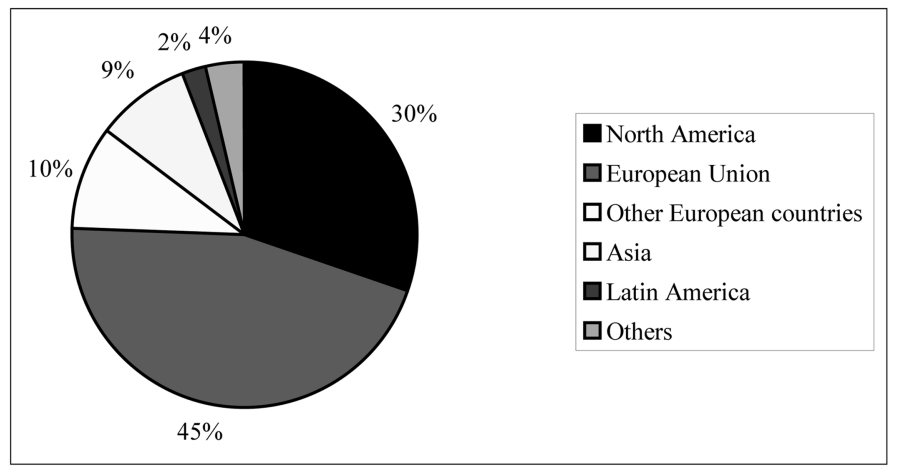

Source : Thomson Financial and our computations

Figure 3. Nmuber of cross-border acquisitons of EU firms (1998-01)

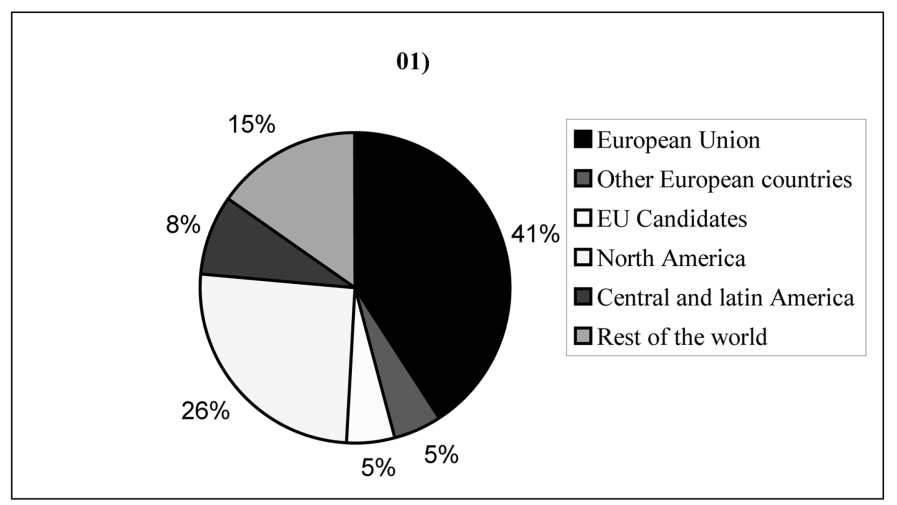

Source : Thomson Financial and our computations

geographic origin of the deals involving a European target.

Figure 3 shows that acquisitions of firms belonging to the European Union (EU) involve in majority others EU firms. Intra-European deals represent $41 \%$ of the number of total European outward flows. Here again, this first impression is confirmed when the value of deals is taken into account. Thus, over the 1998-2001 period, European firms accounted for $46 \%$ of the value of cross-border deals involving a European target.

The predominance of deals inside the European Union may indicate an impact of the process of European integration. Several factors contributed to European integration deepening during that period, namely the completion of the common market and the adoption of the Euro. The prospect of a common currency may 
have induced anticipatory investments by firms, as they seeked to benefit from a more integrated area. This may explain a diversion of investment flows, i.e. that EU firms ceteris paribus tend to acquire others firms from the EU.

In the same perspective, with their reorientation toward Western Europe, the EU candidates from Central and Eastern Europe have increasingly become the destination for FDI flows (Buch et al., 2003). Beyond enhanced democratic stability and low labour costs, investors may have expected that these applying countries would soon be part of the EU and become attractive markets.

However, one should be cautious before attributing the propensity of European firms to preferably merge with or acquire other European firms to the impact of the European integration process. These M\&A flows may have been due to the relative economic and geographic proximity of European economies, which are independent of the process. We therefore need to evaluate the volume of intraEuropean deals that would have occurred absent European integration. With this end in view, we use a gravity model, which we describe in the next section.

\section{Methodology and data}

In this section, we first describe how we adapted the gravity model to bilateral flows of mergers and acquisitions then present the data on which our method was applied.

\section{A. A gravity model with fixed country effects}

The gravity model is one of the success stories of international economics. Originally designed to study trade flows by Beckerman (1956), Tinbergen (1962), or Linnemann (1966), it has since then been applied to capital flows. The best known examples are de Ménil (1999), Wei (2000), or Portes et al. (2001), but older applications of the gravity model to capital flows can be found in Eaton and Tamura (1994), or Ashcroft et al. (1994). The latter provided the only instance of an application of the gravity model to M\&A flows, until di Giovanni (2005).

In its simplest form, the gravity model merely assumes that the flow $\left(F_{i j}\right)$ of capital between two countries, or regions, $i$ and $j$ is a positive function of their mass $\left(M_{i}\right.$ et $\left.M_{j}\right)$, usually defined as some measure of their income, and a negative function of the distance between them $\left(d_{i j}\right)$. However, these core variables are usually complemented by other explanatory variables. These additional determinants of capital flows pertain either to the characteristics of the partner 
countries individually, or to the pair of countries itself. Therefore, the usual specification of the estimated relationship is:

$$
\log \left(F_{i j}\right)=a_{0}+a_{1} \log \left(d_{i j}\right)+A_{1} B_{i j}+a_{2} \log \left(M_{i}\right)+a_{3} \log \left(M_{j}\right)+A_{2} C_{i}+A_{3} C_{j}+\mu_{i j}
$$

where $B_{i j}$ is a vector of the characteristics specific to the pair of countries. $C_{i}$ and $C_{j}$ are vectors containing the characteristics of country $i$ and $j$, respectively. $a_{0}, a_{l}$, $a_{2}$ and $a_{3}$ are scalars. $A_{1}, A_{2}$, and $A_{3}$ are vectors of coefficients applied to the variables describing the characteristics of the pair of countries, of country $i$, and of country $j$.

In the trade literature, geographic distance is interpreted as a proxy for transportation costs. However, such an interpretation may not be as convincing in the context of capital flows as it is for commodity flows. Indeed, unlike goods, capital is insubstantial. There is therefore no ground to believe that the cost of an investment abroad should increase with distance. On the contrary, investors seeking risk diversification should prefer to invest in economies whose business cycles are not correlated with their home country's. Accordingly, they should therefore face an incentive to invest in distant countries. Geographic distance is therefore usually interpreted as a proxy that captures the information and transaction costs associated with international capital flows, as emphasised by Portes et al. (2001). Indeed, firms that evaluate cross-border investment opportunities tend to face informational asymmetries, constituted by the different knowledge of business climate, corporate culture, political events... In particular, Pagano et al. (1999) and Ahearne et al. (2004) establish that different national accounting standards and practices constitute information barriers to cross-border investment. Portes and Rey (2005) invoke some « familiarity effect», as firms and managers from neighbour countries are usually much more familiar with each other, either because of direct relationships in a business or tourism context, because of better media coverage or because of language practices. De Menil (1999), di Giovanni (2005) and Portes and Rey (2005) accordingly interpret geographic distance as a proxy of informational costs. They provide empirical evidence that geographic proximity is an important determinant of international investment decisions, by analysing cross-border capital flows in a gravity set-up.

In the specific context of M\&As, the classic Ownership, Localisation, Internalisation (OLI) paradigm proposed by Dunning (1958) provides additional explanations to the contention that firms value proximity in their decisions to 
acquire, or merge with, foreign firms. Namely, as the cost of managing a subsidiary is likely to increase with geographic distance, the incentive to acquire a foreign affiliate should be greater when the target is relatively closer. The existence of firm-level economies of scale is another reason why international firms may find an advantage in geographic concentration.

The inclusion of variables measuring the mass of the partner countries also seems reasonable. They are usually interpreted as a measure of their supply and market capacities in the context of trade, and this interpretation does not seem heroic when applied to capital flows. However, the concrete definition of a country's mass is more controversial, even in the more restricted literature devoted to capital flows. Thus, some, such as Eaton and Tamura (1994) or Loungani et al. (2002), measure countries' masses by the size of their populations, whereas others, like de Ménil (1999) or Wei (2000), use total GDP. In the context of equity and M\&A flows, more specific size proxies have been used. Namely, Portes et al. (2001) or di Giovanni (2005) use market capitalisation as a measure of a country's size. When studying regional takeovers within the United Kingdom, Ashcroft et al. (1994) employ a region's share in the UK's large firms headquarters to measure its size.

Confronted to the flurry of alternative measures of a country's size, one is left with at least two important questions. First, one must determine which proxy is the most satisfactory, which is problematic due to the apparent lack of consensus on that matter. Second, even if a consensual definition of size was agreed upon, it may well only be available for a very limited set of countries. This is for instance the case of market capitalisation.

Another difficulty of gravity models lies in the choice of the additional countryspecific factors that, beside size and distance, may impact on bilateral trade or M\&A flows. In practice, this means that one must define the composition of matrices $C_{i}$ and $C_{j}$ that describe the characteristics of source and host countries. One cannot be but struck by the diversity of the factors that may influence a country's participation in world investment flows. Research on the determinants of FDI has constantly moved forward by including new factors, some of which may only be crudely proxied.

Thus, even in the still narrow literature that applies gravity models to capital flows, the set of country-specific determinants of FDI flows is impressive. ${ }^{2}$ If the

\footnotetext{
${ }^{2}$ The disheartened reader may find solace in knowing that things are worse when the gravity model is applied to trade. Indeed, in a survey of the literature, Oguledo and MacPhee (1994) list 49 explanatory variables that have been used in previous work.
} 
inclusion of per capita income is fairly standard, more specific variables have also been used. To name but a few, Portes et al. (2001) employ a financial market sophistication measure, while Ashcroft et al. (1994) compute a measure of regional market potential. Wei (2000) focuses on local corruption but also uses fiscal and regulatory variables, as does di Giovanni (2005), who includes the average corporate tax rate among the regressors. Eaton and Tamura (1994) include measures of population density and human capital. However, one may expect that many other variables will be included in the future in gravity models applied to capital flows, as theory and existing empirical work suggest. ${ }^{3}$

Overall, it is therefore reasonable to conclude that, unless one includes an almost endless set of explanatory variables, the result of the estimation is quite likely to suffer from an omitted-variable bias. Moreover, it is doubtful that even such a set of explanatory variables may adequately capture all the unobserved peculiarities of a country, such as culture, specific policies, or factor endowments.

Although these limitations could make one sceptical as to the usefulness of gravity models, some authors, like Màtyàs (1997), Hummels (2001) or Redding and Venables (2004), have recently found a way to sidestep those difficulties, in the context of bilateral trade. These authors estimate a gravity model by including fixed country effects among the regressors. This trick allows these authors both to circumvent the debate on the correct way of measuring a country's mass, and to address the omitted variables problem. Namely, all the pro or anti-trade characteristics of a country are controlled for by that country's dummy, be they measurable or not. Moreover, that solution is particularly parsimonious in terms of data requirements.

In what follows, this is precisely this solution that we apply to M\&A flows. This has, to our knowledge, not been done before for capital flows, let alone M\&As. This strategy allows us to drop all the country-specific variables that appeared in expression (1), and leaves only the variables pertaining to country pairs in the estimation. This is perfectly compatible with the question at hand, since we are interested in M\&A flows between countries that both participate in EMU, which is a bilateral issue. Accordingly, the basic specification of our gravity model is the following:

${ }^{3}$ Chakrabarty (2001) counts eight variables that have been considered as major potential determinants of FDI flows in the cross-country empirical literature. Vasconcellos and Kish (1998) use the exchange rate and the bond yield differential relative to the US to explain a country's attractiveness for M\&As. 


$$
\log \left(F_{i j}\right)=a_{l} \log \left(d_{i j}\right)+A_{l} B_{i j}+f_{i}+f_{j}+\mu_{i j}
$$

where $f_{i}$ is the source country fixed effect and $f_{j}$ the host country fixed effect.

We are now left with defining matrix $B_{i j}$, that consists of variables specific to the pair of countries. Fortunately, the bilateral variables used in the literature are less numerous than country-specific variables, and somewhat less controversial. This should limit the probability of an omitted variable bias.

Accordingly, we include two core bilateral variables in our regressions. As a common language reduces transaction costs and results in greater cultural familiarity, we should expect countries that share a common language to trade more with each other. We therefore add a linguistic dummy to our set of explanatory variables and expect it to bear a positive coefficient. By the same token, we should expect proximity of judicial systems to bear favourably on the volume of cross-border mergers. We therefore complement our set of bilateral variables by a legal dummy that is set equal to one when both countries share the same legal tradition. The coefficient affected to this dummy is expected to be positive. $^{4}$

Now, as we are not interested in estimating a gravity model per se, but wish to use it as a benchmark to assess the impact of the European integration process, we must take the various dimensions of that process into account. The current interpretation of distance in gravity models applied to capital flows as a proxy for information and transaction costs points towards a simple solution. As European integration results in a reduction of administrative impediments and a harmonisation of the legislative framework, as well as in better information, the impact of distance on capital flows should decline between European economies. In other words, we should expect the cost of investing abroad to be smaller between two European countries than for any other pair of countries for a given distance. In our framework, we should expect European integration to decrease the coefficient of geographic distance in the relationship we estimate.

To assess the impact of European integration, we therefore create dummy $e u_{i j}$ that is equal to one when both countries belong to the EU and zero otherwise. We then compute an interaction term, defined as the product of that dummy variable with geographic distance, and include it among the regressors. The specification of

\footnotetext{
${ }^{4}$ We also used a contiguity dummy to account for possible border effects and help correct mismeasurements in geographic distance. However, that variable did not appear significant in any of our regressions and did not affect our main results.
} 
our estimation therefore reads:

$$
\begin{aligned}
& \log \left(F_{i j}\right)=a_{1} \log \left(d_{i j}\right)+a_{2} e u_{i j} \cdot \log \left(d_{i j}\right)+A_{1} B_{i j}+f_{i}+f_{j}+\mu_{i j} \\
& =\left[a_{1}+a_{2} e u_{i j}\right] \log \left(d_{i j}\right)+A_{1} B_{i j}+f_{i}+f_{j}+\mu_{i j}
\end{aligned}
$$

We consequently measure the impact of the EU through its impact on the elasticity of M\&A flows to geographic distance. The intuition behind this interpretation is revealed when the estimated relationship is rearranged like in the second line of expression (3). That expression shows that the coefficient that affects distance consists of two parts, one being a constant, and the other depending on the participation of both countries in the process of European integration. Since all variables are in logs, that coefficient measures the elasticity of M\&A flows to distance. It then clearly appears that coefficient $a_{2}$ measures by how much the participation of both countries in the EU alters the elasticity of M\&A flows to distance. Insofar as we expect the participation of both countries in the EU to be associated with increased capital flows, we expect $a_{2}$ to be positive thereby reducing the impact of distance, which is negative.

The same strategy is also applied to measure the impact of other stages of the process of integration. Thus, we define alternative pair-specific dummies accounting for the participation of both countries in monetary union, and the participation of candidate countries to the process. Those dummies will be precisely defined below but their interpretation remains the same. In a nutshell, our strategy can therefore be said to view European integration as a "distance-saving device".

\section{B. The data}

The cross-border M\&A figures are extracted from the Thomson Financial Products "SCD platinium" database. We consider the number and value of operations implying acquirers from the 15 member countries of the European Union, between 1998 and 2001. 3619 operations involving 15 European acquisition countries and 82 target countries took place during that period.

As "SCD platinium" is supposed to be exhaustive, an absence of reported operation must be interpreted as an absence of operation rather than as an omission. We therefore complemented our data set by replacing missing values by zeros. To make sure that an absence of observation actually meant that no M\&A had occurred, we restricted our sample to countries that already appeared in the data set. In other words, our data set does not contain any country whose number 
of deals would be zero for all source countries. This left us with 1215 observations in the sample, i.e. 1215 bilateral relations registering the outward capital flows from a EU country into either another EU country or a country belonging to the rest of the world.

The period between 1998 and 2001 is of particular interest. First, it coincides with the adoption of the common currency, and the beginning of negotiations with new candidates to EU membership. ${ }^{5}$ Second, this limited period allows the use of cross-section data methods. This period remains representative, as the turning point of the century witnessed the bulk of cross-border M\&A activity, as figure 1 shows. For each pair of countries, we could measure both the number and the value of M\&A deals. We therefore use both as the dependent variable of our estimations.

The gravity data are taken from the CEPII database. ${ }^{6}$ The geographic distance between countries is measured as the surface distance between capital cities. This measure of geographic distance is standard in the literature but is often criticised for not taking into account the fact that capital cities may differ from economic centres. As a robustness check, we therefore also consider the distance separating the most important cities in terms of population, which are considered the economic centre of the country. ${ }^{7}$

The law proximity dummy is equal to one whenever both countries share the same legal principles, i.e. Anglo-Saxon, French, Scandinavian, and socialist tradition. These data are taken from the World Bank's social indicators and fixed factors database.

Furthermore, the common language dummy takes into account the fact that the two countries share the same language. We consider first as well as second language in countries having two official languages. The source for this common language data is the website built by Jon Haveman. ${ }^{8}$ We complemented the

\footnotetext{
${ }^{5}$ Seven countries - Cyprus, Czech Republic, Estonia, Hungary, Malta, Poland and Slovenia - opened negotiations with the EU in March 1998. The second wave of countries applying for the EU membership from February 2000 includes Bulgaria, Latvia, Lithuania, Romania, and the Slovak Republic.

${ }^{6}$ They can be downloaded from http://www.cepii.fr/anglaisgraph/bdd/distances.htm.

${ }^{7}$ For 13 countries out of the 225 countries referenced in the database, the main city differs from the capital city. The concerned countries are Australia (Sydney), Germany (Essen), Benin (Cotonou), Bolivia (La Paz), Brazil (Sao Paulo), United States (New York), Kazakstan (Almaty), Nigeria (Lagos), Ivory Coast (Abidjan), Tanzania (Dar es Salam), Turkey (Istanbul), Canada (Toronto), South Africa (The Cap).

${ }^{8}$ They can be found at the following address http ://www.malacaster.edu/research/economics/PAGE/HAVEMAN/ Trade.Resources/TradeData.html
} 
missing data with the "CIA factbook" website.

Finally, as the estimation is made using logarithms, and $\log (0)$ is undefined, we set $\log (0)=0$ and changed the units of the dependent variable to discriminate between observations with no M\&A and those with one M\&A. ${ }^{9}$ The sample we use is therefore left-censored at zero. Namely, the only pairs of countries that it features are those for which at least one merger or acquisition was observed over the period of study. In other words, all the countries that did not attract capital from a member country are left out of the sample. Consequently, an OLS estimation would provide biased coefficients. We must therefore resort to a Tobit model to estimate expression (3).

\section{Results}

Tables 1 and 2 display the results of our computations. Each relationship was estimated four times, as a robustness check. This means that it was estimated using consecutively the number and the value of deals, and the two measures of distance.

The first result that a quick glance at table 1 reveals is that the gravity model with fixed country effects seems to be a sensible specification. Namely, all variables appear with the predicted sign and are significant. That impression first appears when one looks at the results of the estimation of the benchmark models, which do not control for the effect of European integration and are reported in columns (1), (4), (7), and (10) of table 1. It then appears throughout that geographic distance is a significant impediment to M\&As, whereas the existence of a common law tradition and a common language seem to facilitate such transactions. Moreover, the estimated coefficients are of a constant order of magnitude accross regressions, for a given dependent variable.

Geographic distance being central to our analysis, it deserves a special attention. It is noteworthy that the elasticity of M\&A flows to geographic distance varies slightly, regardless of the distance variable used. One may also notice that all the other coefficients remain of the same order of magnitude, regardless of the distance variable used. Furthermore, the distance coefficients we obtained are also of a similar order of magnitude as those found by di Giovanni (2005).

On the other hand, the sensitivities of the number and value of deals to explanatory variables differs. Thus, it appears that the value of deals is more elastic

\footnotetext{
${ }^{9}$ As the estimated coefficients are elasticities, they are independent from the units in which the variables are measured. That transformation therefore did not affect our results.
} 
Table 1. results

\begin{tabular}{|c|c|c|c|c|c|c|c|c|c|c|c|c|}
\hline \multirow{3}{*}{$\begin{array}{l}\begin{array}{l}\text { Dependent vari- } \\
\text { able }\end{array} \\
\text { Distance } \\
\end{array}$} & \multicolumn{6}{|c|}{ Number of M\&As } & \multicolumn{6}{|c|}{ Value of M\&As } \\
\hline & \multicolumn{3}{|c|}{ Between capitals } & \multicolumn{3}{|c|}{ Between main cities } & \multicolumn{3}{|c|}{ Between capitals } & \multicolumn{3}{|c|}{ Between main cities } \\
\hline & (1) & (2) & (3) & (4) & (5) & (6) & (7) & (8) & (9) & (10) & (11) & (12) \\
\hline $\begin{array}{l}\text { Distance } \\
\text { between capitals }\end{array}$ & $\begin{array}{c}-2.660 * * * \\
(7.53)\end{array}$ & $\begin{array}{c}-2.694 * * * \\
(7.55)\end{array}$ & $\begin{array}{c}-3.983^{* * *} \\
(8.35)\end{array}$ & & & & $\begin{array}{c}-4.493^{* * *} \\
(7.52)\end{array}$ & $\begin{array}{c}-4.560 * * * \\
(7.56)\end{array}$ & $\begin{array}{c}-6.659 * * * \\
(8.21)\end{array}$ & & & \\
\hline $\begin{array}{l}\text { Distance } \\
\text { between main } \\
\text { cities }\end{array}$ & & & & $\begin{array}{c}-2.365 * * * \\
(6.93)\end{array}$ & $\begin{array}{c}-2.385 * * * \\
(6.94)\end{array}$ & $\begin{array}{c}-3.889 * * * \\
(8.01)\end{array}$ & & & & $\begin{array}{c}-4.076^{* * *} \\
(7.09)\end{array}$ & $\begin{array}{c}-4.116^{* * *} \\
(7.11)\end{array}$ & $\begin{array}{c}-6.557^{* * *} \\
(7.96)\end{array}$ \\
\hline $\begin{array}{l}\text { Common } \\
\text { language }\end{array}$ & $\begin{array}{c}3.435^{* * *} \\
(5.09)\end{array}$ & $\begin{array}{c}3.478^{* * *} \\
(5.13)\end{array}$ & $\begin{array}{c}3.588^{* * *} \\
(5.35)\end{array}$ & $\begin{array}{c}3.527^{* * * *} \\
(5.19)\end{array}$ & $\begin{array}{c}3.557 * * * \\
(5.21)\end{array}$ & $\begin{array}{c}3.613 * * * \\
(5.36)\end{array}$ & $\begin{array}{c}5.598 * * * \\
(4.92)\end{array}$ & $\begin{array}{c}5.681^{* * * *} \\
(4.97)\end{array}$ & $\begin{array}{l}5.851^{* * *} \\
(5.16)\end{array}$ & $\begin{array}{c}5.721 \text { *** } \\
(5.01)\end{array}$ & $\begin{array}{c}5.784^{* * *} \\
(5.04)\end{array}$ & $\begin{array}{c}5.865 \text { *** } \\
(5.17)\end{array}$ \\
\hline Law proximity & $\begin{array}{c}0.952 * * \\
(2.27)\end{array}$ & $\begin{array}{c}0.898 * * \\
(2.11)\end{array}$ & $\begin{array}{c}1.006 * * \\
(2.42)\end{array}$ & $\begin{array}{c}1.100^{* * * *} \\
(2.63)\end{array}$ & $\begin{array}{c}1.063 * * \\
(2.50)\end{array}$ & $\begin{array}{c}1.096 * * * \\
(2.63)\end{array}$ & $\begin{array}{c}1.868 * * * \\
(2.65)\end{array}$ & $\begin{array}{c}1.763 * * \\
(2.46)\end{array}$ & $\begin{array}{c}1.954 * * * \\
(2.79)\end{array}$ & $\begin{array}{c}2.105 * * * \\
(2.99)\end{array}$ & $\begin{array}{c}2.028 * * * \\
(2.84)\end{array}$ & $\begin{array}{c}2.099 * * * \\
(3.00)\end{array}$ \\
\hline $\begin{array}{l}\text { EMU- } 12 \times \text { dist. } \\
\text { bet. capitals }\end{array}$ & & $\begin{array}{l}0.081 \\
(0.73)\end{array}$ & & & & & & $\begin{array}{l}0.157 \\
(0.84)\end{array}$ & & & & \\
\hline $\begin{array}{l}\text { European Union } \\
\times \text { dist. bet. capitals }\end{array}$ & & & $\begin{array}{c}2.856 * * * \\
(4.18)\end{array}$ & & & & & & $\begin{array}{c}4.632 * * * \\
(4.00)\end{array}$ & & & \\
\hline $\begin{array}{l}\text { EMU-12 } 12 \text { dist. } \\
\text { bet. cities }\end{array}$ & & & & & $\begin{array}{l}0.055 \\
(0.49)\end{array}$ & & & & & & $\begin{array}{l}0.115 \\
(0.61)\end{array}$ & \\
\hline $\begin{array}{l}\text { European Union } \\
\times \text { dist. bet. cities }\end{array}$ & & & & & & $\begin{array}{c}2.985 * * * \\
(4.44)\end{array}$ & & & & & & $\begin{array}{c}4.825^{* * *} \\
(4.24)\end{array}$ \\
\hline Sigma & $\begin{array}{c}3.464 * * * \\
(28.32)\end{array}$ & $\begin{array}{c}3.464 * * * \\
(28.31)\end{array}$ & $\begin{array}{c}3.431 * * * \\
(28.32)\end{array}$ & $\begin{array}{c}3.487 * * * \\
(28.29)\end{array}$ & $\begin{array}{c}3.487 * * * \\
(28.29)\end{array}$ & $\begin{array}{c}3.448 * * * \\
(28.31)\end{array}$ & $\begin{array}{c}5.832 * * * \\
(27.61)\end{array}$ & $\begin{array}{c}5.832 * * * \\
(27.61)\end{array}$ & $\begin{array}{c}5.787 * * * \\
(27.63)\end{array}$ & $\begin{array}{l}5.856^{* * *} \\
(27.60)\end{array}$ & $\begin{array}{l}5.856^{* * *} \\
(27.59)\end{array}$ & $\begin{array}{c}5.803^{* * *} \\
(27.62)\end{array}$ \\
\hline Observations & 1215 & 1215 & 1215 & 1215 & 1215 & 1215 & 1215 & 1215 & 1215 & 1215 & 1215 & 1215 \\
\hline Log-likelihood & -1439 & -1438 & -1430 & -1443 & -1443 & -1433 & -1660 & -1659 & -1652 & -1663 & -1663 & -1656 \\
\hline
\end{tabular}

Absolute t-statistics are displayed in parentheses under the coefficient estimates. *: test-statistic is significant at the $10 \%$ level ; **: $5 \%$ level ; ***: $1 \%$ level. Fixed effects are not reported. 
Table 2. results

\begin{tabular}{|c|c|c|c|c|c|c|c|c|c|c|c|c|}
\hline \multirow{3}{*}{$\begin{array}{c}\text { Dependent variable } \\
\text { Distance }\end{array}$} & \multicolumn{6}{|c|}{ Number of M\&As } & \multicolumn{6}{|c|}{ Value of M\&As } \\
\hline & \multicolumn{3}{|c|}{ Between capitals } & \multicolumn{3}{|c|}{ Between main cities } & \multicolumn{3}{|c|}{ Between capitals } & \multicolumn{3}{|c|}{ Between main cities } \\
\hline & (13) & (14) & (15) & (16) & (17) & (18) & (19) & (20) & (21) & (22) & (23) & (24) \\
\hline $\begin{array}{l}\text { Distance } \\
\text { between capitals }\end{array}$ & $\begin{array}{c}-4.217^{* * *} \\
(7.27)\end{array}$ & $\begin{array}{c}-3.873^{* * *} \\
(6.13)\end{array}$ & $\begin{array}{c}-4.075^{* * *} \\
(6.57)\end{array}$ & & & & $\begin{array}{c}-7.389^{* * *} \\
(7.52)\end{array}$ & $\begin{array}{c}-6.749 * * * \\
(6.31)\end{array}$ & $\begin{array}{c}-7.219^{* * * *} \\
(6.88)\end{array}$ & & & \\
\hline $\begin{array}{l}\text { Distance between } \\
\text { main cities }\end{array}$ & & & & $\begin{array}{c}-3.962 * * * \\
(6.81)\end{array}$ & $\begin{array}{c}-3.622 * * * \\
(5.72)\end{array}$ & $\begin{array}{c}-3.834 * * * \\
(6.16)\end{array}$ & & & & $\begin{array}{c}-7.011^{* * *} \\
(7.13)\end{array}$ & $\begin{array}{c}-6.330^{* * *} \\
(5.92)\end{array}$ & $\begin{array}{c}-6.831 * * * \\
(6.51)\end{array}$ \\
\hline Common language & $\begin{array}{c}3.515^{* * *} \\
(5.23)\end{array}$ & $\begin{array}{c}3.469 * * * \\
(5.14)\end{array}$ & $\begin{array}{l}3.476^{* * *} \\
(5.16)\end{array}$ & $\begin{array}{c}3.57^{* * * *} \\
(5.28)\end{array}$ & $\begin{array}{c}3.538^{* * * *} \\
(5.22)\end{array}$ & $\begin{array}{l}3.540^{* * *} \\
(5.23)\end{array}$ & $\begin{array}{c}5.744^{* * * *} \\
(5.08)\end{array}$ & $\begin{array}{c}5.660 * * * \\
(4.99)\end{array}$ & $\begin{array}{c}5.776^{* * * *} \\
(5.01)\end{array}$ & $\begin{array}{l}5.798^{* * *} \\
(5.11)\end{array}$ & $\begin{array}{l}5.741^{* * *} \\
(5.04)\end{array}$ & $\begin{array}{l}5.746 * * * \\
(5.06)\end{array}$ \\
\hline Law proximity & $\begin{array}{l}0.950^{* *} \\
(2.28)\end{array}$ & $\begin{array}{c}0.955 * * \\
(2.28)\end{array}$ & $\begin{array}{c}0.958 * * \\
(2.29)\end{array}$ & $\begin{array}{l}1.066^{* *} \\
(2.55)\end{array}$ & $\begin{array}{c}1.082^{* * *} \\
(2.58)\end{array}$ & $\begin{array}{c}1.081^{* * *} \\
(2.58)\end{array}$ & $\begin{array}{c}1.864 * * * \\
(2.66)\end{array}$ & $\begin{array}{c}1.873 * * * \\
(2.66)\end{array}$ & $\begin{array}{c}1.879^{* * *} \\
(2.68)\end{array}$ & $\begin{array}{c}2.042 * * * \\
(2.92)\end{array}$ & $\begin{array}{l}2.071^{* * *} \\
(2.95)\end{array}$ & $\begin{array}{c}2.067 * * * \\
(2.95)\end{array}$ \\
\hline $\begin{array}{l}\text { 1st enlargement } \times \\
\text { dist. bet. capitals }\end{array}$ & $\begin{array}{c}2.380 * * * \\
(3.41)\end{array}$ & & & & & & $\begin{array}{c}4.417 * * * \\
(3.73)\end{array}$ & & & & & \\
\hline $\begin{array}{l}\text { 2nd enlargement } \times \\
\text { dist. bet. capitals }\end{array}$ & & $\begin{array}{c}1.693 * * \\
(2.32)\end{array}$ & & & & & & $\begin{array}{l}3.149 * * \\
(2.55)\end{array}$ & & & & \\
\hline $\begin{array}{l}\text { EU-25 } \times \\
\text { dist. bet. capitals }\end{array}$ & & & $\begin{array}{l}2.015^{* * *} \\
(2.78)\end{array}$ & & & & & & $\begin{array}{c}3.884^{* * *} \\
(3.17)\end{array}$ & & & \\
\hline $\begin{array}{l}1 \text { st enlargement } \\
\times \text { dist. bet. main cities }\end{array}$ & & & & $\begin{array}{l}2.364 * * * \\
\quad(3.40)\end{array}$ & & & & & & $\begin{array}{c}4.340^{* * *} \\
(3.69)\end{array}$ & & \\
\hline $\begin{array}{l}\text { 2nd enlargement } \times \\
\text { dist. bet. main cities }\end{array}$ & & & & & $\begin{array}{r}1.715^{* *} \\
(2.36)\end{array}$ & & & & & & $\begin{array}{c}3.076^{* *} \\
(2.50)\end{array}$ & \\
\hline $\begin{array}{l}\text { EU- } 25 \times \\
\text { dist. bet. main cities }\end{array}$ & & & & & & $\begin{array}{c}2.041^{* * *} \\
(2.83)\end{array}$ & & & & & & $\begin{array}{c}3.831 * * * \\
(3.15)\end{array}$ \\
\hline Sigma & $\begin{array}{c}3.444^{* * *} \\
(28.32)\end{array}$ & $\begin{array}{c}3.457^{* * * *} \\
(28.31)\end{array}$ & $\begin{array}{c}3.451^{* * *} \\
(28.31)\end{array}$ & $\begin{array}{c}3.466 * * * \\
(28.30)\end{array}$ & $\begin{array}{c}3.479 * * * \\
(28.29)\end{array}$ & $\begin{array}{c}3.478^{* * *} \\
(28.29)\end{array}$ & $\begin{array}{c}5.787 * * * \\
(27.63)\end{array}$ & $\begin{array}{c}5.815^{* * *} \\
(27.62)\end{array}$ & $\begin{array}{c}5.800^{* * * *} \\
(27.63)\end{array}$ & $\begin{array}{c}5.811 * * * \\
(27.62)\end{array}$ & $\begin{array}{c}5.839^{* * * *} \\
(27.60)\end{array}$ & $\begin{array}{c}5.824 * * * \\
(27.61)\end{array}$ \\
\hline Observations & 1215 & 1215 & 1215 & 1215 & 1215 & 1215 & 1215 & 1215 & 1215 & 1215 & 1215 & 1215 \\
\hline Log-likelihood & -1430 & -1436 & -1435 & -1437 & -1440 & -1439 & -1653 & -1656 & -1655 & -1656 & -1660 & -1658 \\
\hline
\end{tabular}

Absolute $t$-statistics are displayed in parentheses under the coefficient estimates. *: test-statistic is significant at the $10 \%$ level; **: $5 \%$ level; ***: $1 \%$ level. Fixed effects are not reported. 
to geographic distance, to the existence of a common language, and to the proximity of judicial systems than the number of deals. This finding may be due to the influence of a few European mega-deals, such as Vodafone-Manesmann or Rhône Poulenc-Hoechst, that impacted the value of deals more than their number.

In the rest of the displayed regressions, we assess the impact of various dimensions of the process of European integration, following the method described in the previous sections. We therefore first focus on the impact of monetary union and of the fifteen member European Union, in table 1. We then consider enlarged EUs, by including countries that had voiced their intention to join the EU at the time the data we use were collected in the definition of the European integration dummy. We finally consider the latest configuration of the EU, i.e. that with 25 members. The results pertaining to present EU members and candidate countries or the new EU are reported in table 2.

Table 1 first reports the results for countries that were members of the EU during the period of study. More precisely, the results pertain to both EMU and EU membership. As mentioned in the previous section, the dummy variable used in the interaction term therefore takes the value one whenever the two countries of a country-pair both belong to the EMU (regressions (2), (5), (8), and (11)), or the EU (regressions (3), (6), (9), and (12)). ${ }^{10}$

Regressions (2), (5), (8), and (11) show that, though always intuitively signed, the interaction term that accounts for the participation of two countries in the EMU is not significantly associated with neither the number nor the value of M\&A deals between them. Besides, the inclusion of that interaction term does not affect other variables. It therefore appears that the participation of two countries in EMU does not seem to significantly alter the elasticity on distance of neither the number nor the value of M\&A deals between them. In a nutshell, it does not seem that the nonparticipation of Denmark, the UK, or Sweden, in EMU had a significant impact on their relationship with other EU members over our period of study.

Regressions (3), (6), (9), and (12) suggest on the opposite that the participation of two countries in the EU has a significant impact on their bilateral M\&A flows. Namely, the interaction term for EU membership is always significantly positive. Moreover, in all regressions, it approximately amounts to two thirds of the coefficient on distance. In other words, according to our point estimates, the parti-

\footnotetext{
${ }^{10}$ The definition of the eurozone that we used in the reported results involves twelve countries. We also tested the impact of the early eleven member eurozone, i.e. Greece was excluded, but the results were the same and are therefore not reported.
} 
cipation of two countries in the EU divides the elasticity of M\&A flows to geographic distance by four. Therefore the EU had a statistically significant impact on M\&A flows over our period of study. ${ }^{11}$ One may even somewhat humorously venture to say that it achieved the goal set by the founding fathers of bringing European countries closer to each other.

The inclusion of the EU interaction term warrants more comments. Thus, it appears that the coefficient of the distance variable always increases in absolute terms relative to its benchmark value. That coefficient measures the elasticity to geographic distance of M\&A flows between two countries that do not both partake in the EU. This suggests that not discriminating between EU and non-EU country pairs may bias downward the estimation of the elasticity of M\&A flows to geographic distance. The estimated coefficient would thus amount to an average between the elasticities to distance of the M\&A flows between the two sets of pairs of countries.

Table 2 displays the results that were obtained when candidate countries or new members were added to the set of actual members of the EU. We distinguished the first circle of candidate countries from the latecomers, which applied in February 2000. We accordingly created two additional dummy variables. The first one was set equal to one whenever both the source and target countries belonged either to the EU or to the first set of candidates, and zero otherwise. The second one was set to one whenever both countries belonged to any group of countries participating in the process of European integration, namely member countries and candidates from either wave. Our dummies therefore include concentric subsets of countries by order of decreasing integration. The final dummy considers the present enlarged EU, which includes 25 countries. $^{12}$ It is set to one whenever both partners belong to that configuration of the EU.

A quick glance at table 2 reveals that interaction terms are always positive and significant, regardless of the dependent variable and the definition of geographic distance. It therefore appears that M\&A flows between past and future members of the EU were less affected by distance than between other pairs of countries.

\footnotetext{
${ }^{11}$ The quantitative impact of EU however depends on the distance between countries. As we estimate its impact on the elasticity of M\&A flows to distance, a pair of countries should benefit more from their participation in the EU if they are further apart.

${ }^{12}$ To wit, the ten following countries are added to the first fifteen members: Cyprus, Czech Republic, Estonia, Hungary, Latvia, Lithuania, Malta, Poland, Slovenia, and the Slovak Republic. Bulgaria and Romania, which both belonged to the second wave of candidate countries, did not enter the EU on 1 May 2004.
} 
Quantitatively, the impact is larger for the first wave than for the EU25, whose impact is in turn larger than for the second wave. Intuitively, this result can be attributed to the chronology of candidacies, and to the fact that the probability of integrating the EU by May 2004 was larger for earlier candidate countries, which may have dissuaded potential M\&As. One must indeed bear in mind that our sample spans the 1998-2001 period, whereas the candidacy of the second wave of candidates was only officially announced in 2000 . Their candidacy may then have been too recent to impact M\&A flows over our period of study.

\section{Conclusion}

In this paper, we applied a gravity model with fixed country effects to M\&A flows over the 1998-2001 period, which was the peak of the nineties' wave of M\&As, and tested the impact of various dimensions of European integration. The results are twofold. First, it appears that such a model can be successfully applied to M\&A flows. This is important, as it solves the risk of an omitted-variable bias in the estimated coefficients. That model had, to our knowledge, only been applied to flows of goods and services. Our results show that it is applicable to other bilateral trade flows, which may prove useful for subsequent investigations.

Second, the model allowed us to assess the impact of the process of European integration on M\&A flows. In a nutshell, one may say that we observed a specificity of intra-European M\&A flows over our period of study, insofar as our estimates suggest that the impact of geographic distance on bilateral M\&A flows is reduced when two countries participate in the process of European integration. This general diagnosis can moreover be qualified, as our computations allow one to determine the dimensions of integration that most impact the M\&A activity. Thus, we could observe no specificity of intra-eurozone M\&As. We could however observe specificity of M\&A flows between the first fifteen members of the EU and their partners, defined as countries participating in the EU15, or the EU25, or candidate countries from either wave. The observed impact was quantitatively larger for smaller subsets of countries.

However suggestive, our results warrant further investigations, for instance by focusing on a larger period of study, or by testing other determinants of M\&A flows. This paves the way for further research, made possible by the method used here. 


\section{References}

Ahearne A. G., W.L. Griever and F.E. Warnock (2004) "Information costs and home bias: an analysis of US holdings of foreign equities". Journal of International Economics. 62, 313-336.

Ashcroft B., B. Coppins, and R. Raeside (1994) "The regional dimension of takeover activity in the united kingdom". Scottish Journal of Political Economy. 41, 163-175.

Beckerman W. (1956) "Distance and the pattern of intra-European trade". Review of Economics and Statistics. 38.

Buch C.M., R.M. Kokta, and D. Piazolo (2003) "Foreign direct investment in Europe: is there redirection from the south to the east?". Journal of Comparative Economics. 31. 94-109.

Chakrabarti A. (2001) "The determinants of foreign direct investment: sensitivity analyses of cross-country regressions". Kyklos. 54, 89-113.

de Ménil G. (1999) "Real capital market integration in the EU: how far has it gone? What will the effect of the euro be?". Economic Policy. 28, 165-189.

di Giovanni J. (2005) "What drives capital flows? The case of cross-border M\&A activity and financial deepening". Journal of International Economics, 65, 127-149.

Dunning J. (1958) American investment in British manufacturing industry. Gearg Allen and Unwin, London.

Eaton J. and A. Tamura (1994) "Bilateralism and regionalism in Japanese and U.S. trade and direct foreign investment patterns". Journal of the Japanese and International Economies. 8, 478-510.

Hummels D. (2001) "Toward a geography of trade costs". working paper. University of Purdue. September.

Krugman P. (1993) "Lessons of Massachusetts for EMU". in Torres F. and F. Giavazzi (Eds.). Adjustment and Growth in the European Monetary Union. Cambridge University Press, New York.

Linnemann H. (1966) An econometric study of international trade flows. North Holland, Amsterdam.

Loungani P., Mody A. and. A. Razin (2002) "The global disconnect: The role of transactional distance and scale economies in gravity equations". Scottish Journal of Political Economy. 49, 526-543.

Màtyàs L. (1997) "Proper econometric specification of the gravity model". World Economy. 20. 363-368.

Mélitz J. and F. Zumer (1999) "Interregional and international risk-sharing and lessons for EMU”. Carnegie-Rochester Conference Series on Public Policy. 51, 149-188.

Oguledo V.I. and MacPhee (1994) "Gravity models: A reformulation and an application to discriminatory trade agreements". Applied Economics. 26, 107-120.

Pagano M., A.A. Roell and J. Zechner (2001) "The Geography of Equity Listing: Why Do European Companies List Abroad?', University of Salerno, Centre for Studies in Economics 
and Finance Working Paper 28.

Portes R.. H. Rey and Y. Oh (2001) "Information and capital flows: the determinants of transactions in financial assets". European Economic Review. 45, 783-796.

Portes R. and H. Rey (2005) "The determinants of cross-border equity flows", Journal of International Economics. 65, 269-296.

Pryor. F.L. (2001) "Dimensions of the worldwide merger boom". Journal of Economic Issues. 35, 825-840.

Redding S. and A.J. Venables (2004) "Economic geography and international inequality". Journal of International Economics. 62, 53-82.

Tinbergen J. (1962) Shaping the world economy: suggestions for an international economic policy. Twentieth Century Fund. New York.

Vasconcellos G.M. and R.J. Kish (1998) "Cross-border mergers and acquisitions: the European-US experience”. Journal of Multinational Financial Management. 8, 431450.

Wei S.-J. (2000) "Local corruption and global capital flows". Brookings Papers on Economic Activity. 2, 303-354. 